\title{
FIREFORCE - ONE MAN'S WAR IN THE RHODESIAN LIGHT INFANTRY
}

Chris Cocks

Covos Books, Roodepoort: 1998

ISBN 0-620-21573-9

R 185-00

"They have the faces of boys but they fight like lions"

The history of the Rhodesian Light Infantry is an illustrious one. The RLI produced many of the senior brass who led the Rhodesian Army including Gen Peter Walls. It was arguably Rhodesia's premier fighting unit (if one excludes Rhodesia's two special forces outfits, the Special Air Service and the Selous Scouts). The spirit of the RLI runs deep in Rhodesian military lore, it was to all intents and purposes a unique Regiment. The RLI was a regular unit, which absorbed many young conscripts. It was also one of the Rhodesian Army's premier frontline regiments alongside the Rhodesian African Rifles, the Scouts and the SAS. The fundamental difference between the RLI and these other units was that the RLI was a mixture of conscripts and regulars whereas the remaining three units made use of regular volunteers and territorials.

The author of this book, Chris Cocks, was a teenage conscript in the RLI and this is his story. This book is a challenge to the straightforward writing of Military History, where so many historians choose to focus on prominent personalities and battlefield tactics. This is the story of a soldier's war - it is a gripping and bittersweet look at Army life. Cocks brings the constant thread of death to the forefront of this book. At no time does he attempt to disguise the brutality of the Bush War or hide the atrocities, which were committed by troops and guerillas alike. The writer's own sense of doubt as to whether this was a just cause adds a further dimension to the book. Many of the young Rhodesian conscripts accepted the status quo without question, others, like Cocks were constantly plagued by the morality of a war that ultimately witnessed a society feeding upon itself. 
For the military enthusiast, Fireforce is loaded with vivid descriptions of tense contacts, detailed description of weaponry and discussion on the tactics favoured by the Rhodesian Infantry at that time. If you enjoyed Ron Reid Daly's "'Selous Scouts or Barbara Cole's "The Elite"" then you will find that Fireforce completes the trilogy. The RLI Fireforce teams were usually summoned into action by the Selous Scouts pseudo sticks. However, whereas the Scouts were seasoned professionals, the average RLI Commando was an inexperienced and very young soldier. The author does well in conveying the sense of mounting anticipation, apprehension and nausea, which must accompany any greenhorn on operations. The mental and physical nervous exhaustion of fighting a hot war is a recurring and strong theme throughout the book.

There are many different characters in Fireforce, but to his credit Chris Cocks has employed really effective character formulation, to the extent that he brings the book to life. Sadly as the story unfolds, the characters begin to diminish, one by one as they are killed in battle, wounded or eventually desert the Army and Rhodesia. It is desperate stuff, and it brings home the saddest truth about war, that it normally claims the young as its first victims. To a large extent this is the essence of this work, the loneliness and fear that one feels in war and the long term effects of a war, especially a civil war. Most of those who fought alongside Cocks and survived the Bush War died later, either by suicide, alcohol abuse or in car accidents.

Fireforce has its lighter moments too. Chris Cocks has an excellent turn of phrase and a quick, dry sense of humour. The tales of the various troopies exploits are brought vividly to life. He successfully manages to recreate the atmosphere of the time and combines this well with the trials and tribulations of passing from adolescence into adulthood.

Fireforce is a hardcover book in an attractive dustcover. The book contains three sections of colour photographs, mainly taken from Chris Cocks' private collection'. The author has also commendable attention to detail and has included rather definitive technical appendixes. To many 
readers this technical jargon is rather meaningless but no doubt certain 'nuts and bolts" junkies will appreciate the information. The inclusion of the regiments' roll of honour and decoration citations provides an extremely useful research tool reflects the ravages of the War on the RLI.

This is the first account that I have read of the Rhodesian War that was written by an ordinary soldier. Many other excellent books on the war or the history of certain units exist, but Fireforce is unique given the perspective that it offers. Fireforce has also been hailed in certain quarters as the definitive work on counter-insurgency warfare in Africa. It is certainly worthy of the widespread critical acclaim, which has been heaped upon it.

Covos books have a website at www.members.tripod.com/covos

Noëlle van der Waag-Cowling, Department of Academic Development, Faculty of Military Science, University of Stellenbosch 


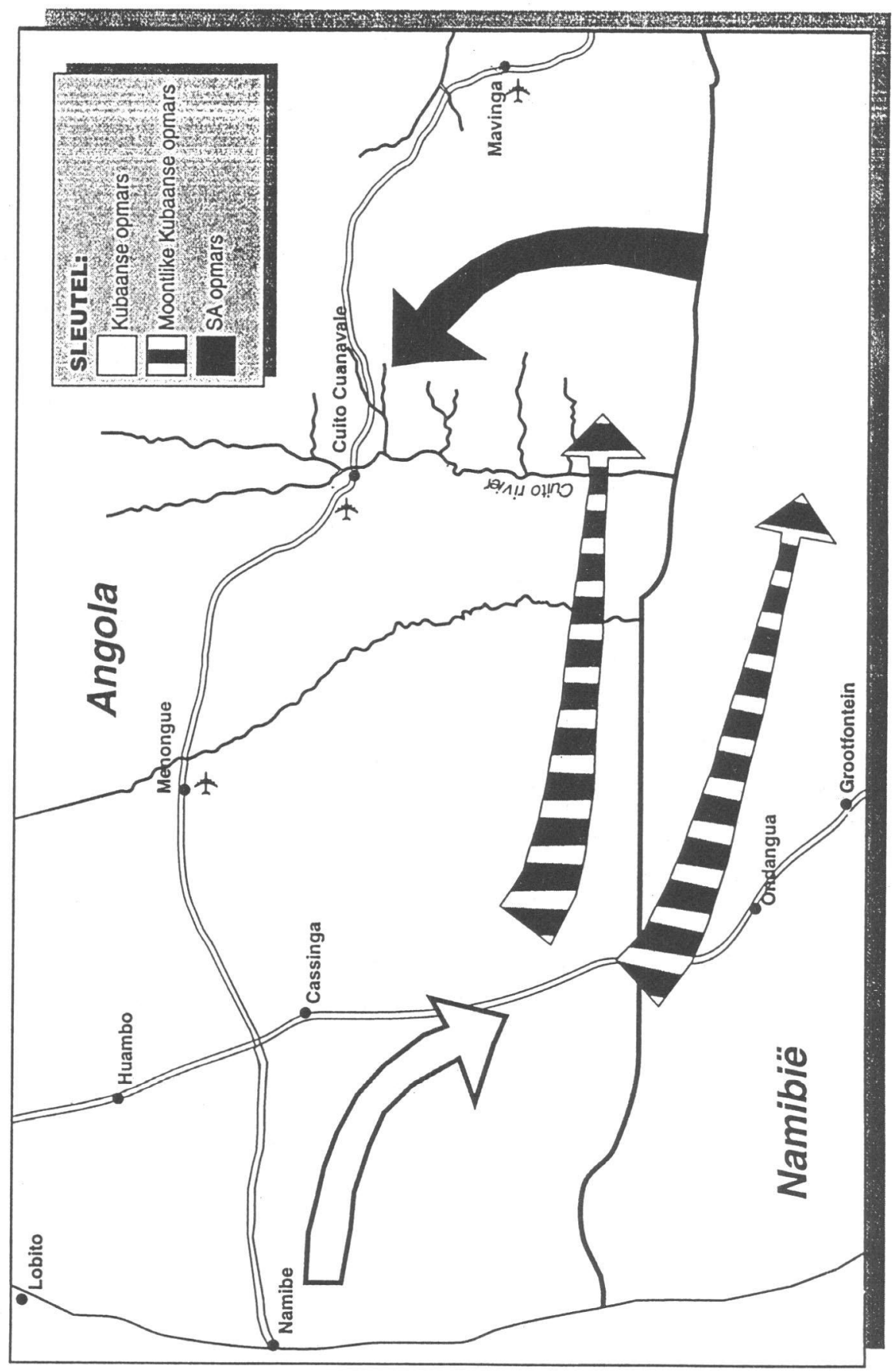

